\title{
Phytotherapic medication toxity index: a literature review
}

\author{
Ana Beatriz Queiroz de Souza ${ }^{1 *}$; Sidrielly Cecilia Clarice de Assunção²; Maria Karollyne dos Santos \\ Paiva $^{3}$; Bruna Gabriela Lacerda ${ }^{4}$; Stéfani Gomes da Silva ${ }^{5}$; Raynara Rutielly Alexandre Mendonça ${ }^{6}$; \\ Isabela Natália Arcanjo Mendes ${ }^{7}$; Lorena Daphine Pessoa Santos ${ }^{8}$; Igor Gabriel de Souza Gomes ${ }^{9}$; \\ Ewerton de Carvalho Nascimento ${ }^{10}$; Maria Clara Bezerra Gabu ${ }^{11}$; Lucielma Barbosa de Souza \\ Oliveira $^{12}$
}

1 - 7 Graduated in Bachelor's Degree in Pharmacy from the University Center of Vitória de Santo Antão -UNIVISA

8 - 9 Graduated in Bachelor's Degree in Pharmacy from The Facol University Center -UNIFACOL

10 Graduating in Bachelor of Pharmacy from the University Center of Vitória de Santo Antão -UNIVISA

11 Graduated in Bachelor's Degree in Physiotherapy from the University Center of Vitória de Santo Antão -UNIVISA

12 Graduated in Bachelor's Degree in Nursing from the University Center of Vitória de Santo Antão -UNIVISA

E-mail adresses: biasouzaq609@gmail.com (Ana Beatriz Queiroz de Souza), sidriellyassuncao@gmail.com (Sidrielly Cecilia Clarice de Assunção), karollynemaria1@gmail.com (Maria Karollyne dos Santos Paiva), lacerdab004@gmail.com (Bruna Gabriela Lacerda), stefani.gomess200@gmail.com (Stéfani Gomes da Silva), raynara.ruth01@outlook.com (Raynara Rutielly Alexandre Mendonça), isabelanatalia86@gmail.com (Isabela Natália Arcanjo Mendes), lorenadaphine17@outlook.com (Lorena Daphine Pessoa Santos), Igorsouza9128@gmail.com (Igor Gabriel de Souza Gomes), ewertoncarvalho1@gmail.com (Ewerton de Carvalho Nascimento), clara.gabu91@gmail.com (Maria Clara Bezerra Gabu), LucielmaBarbosa2020@gmail.com (Lucielma Barbosa de Souza Oliveira).

${ }^{*}$ Corresponding author

\section{To cite this article:}

Souza, A.B.Q.; Assunção, S.C.C.; Paiva, M.K.S.; Lacerda, B.G.; Silva, S.G.; Mendonça, R.R.A.; Mendes, I.N.A.; Santos, L.D.P.; Gomes, I.G.S.; Nascimento, E.C.; Gabu, M.C.B.; Oliveira, L.B.S. Phytotherapic medication toxity index: a literature review. International Journal of Sciences. Vol. 2, No. 3, 2021, pp. 62-65. ISSN 2763-5392.

Received: 10 14, 2021; Accepted: 10 15, 2021; Published: 11 03, 2021

\begin{abstract}
The use of herbal medicines as a form of relief and treatment of diseases is a widely used practice and this culture remains included in modern medicine to this day. The potential toxicity of each plant is specific, as each plant can express a different pharmacological effect. To assist in this issue, FIOCRUZ's National Toxic-Pharmacological Information System (SINITOX) has as its main attribution to coordinate the collection, compilation, analysis and dissemination of cases of intoxication and poisoning reported in the country. This study aims to describe the toxicity, effects and undesirable reactions of herbal medicines through the literature review. The study is defined as a systematic review of the literature based on bibliographic research through articles and scientific publications of reference in the area between the years 2012 and 2021 . According to Freitas and Mendonça in 2019 reported that there is fear among doctors at the time of prescription due to side effects. There are few reports of herbal poisoning, caused by self-medication, low quality product and high dosages. And, as a way to reduce the risks to the population, the Ministry of Health (MS) reported 71 species of medicinal plants in the list of National List of Medicinal Plants being governed by the SUS. In Brazil, there has been a gradual guarantee of access to medicines and their rational use, especially herbal medicines. Including a series of drug-focused procedures needed to promote, prevent and restore individual and collective health.
\end{abstract}

Keywords: Phytotherapic medication; Medicinal Plants; Pharmaceutical Assistance; Intoxication.

\section{Introduction}

The use of herbal medicines as a form of relief and treatment of diseases is a widely used practice and this culture remains included in modern medicine to this day (LEE et al., 2019). Knowledge about use has been passed on since antiquity, this attitude is greatly influenced by close relatives. However, free access to plants makes people believe that their 
2 Souza, A.B.Q.; Assunção, S.C.C.; Paiva, M.K.S.; Lacerda, B.G.; Silva, S.G.; Mendonça, R.R.A.; Mendes, I.N.A.; Santos, L.D.P.; Gomes, I.G.S.; Nascimento, E.C.; Gabu, M.C.B.; Oliveira, L.B.S. Phytotherapic medication toxity index: a literature review...

use does not require guidance (RIBOLDI; RIGO, 2019). In 1978, the World Health Organization (WHO) began to apply phytotherapy and the use of medicinal plants in various forms of medicine. However, unreasonable use has led to cases of intoxications (ALMEIDA et al., 2019).

The Unified Health System (SUS) recommends the use of plants as a source of innovation in health and Brazilian Decree No. 5,813 / 2006 guarantees their use as long as it promotes the well-being of users and the sustainability of plant biodiversity. (Brazil, 2016). Primary Health Care (ABS) functions as a gateway to the SUS, through which professionals can work with the population on issues important to the community and ensuring knowledge about the rational use of medicinal plants and their interactions with medicines and plants (ALENCAR et al. 2019).

The potential toxicity of each plant is specific, as each plant can express a different pharmacological effect. (PINHEIRO et al., 2020) and in relation to side effects caused by poisoning scans such as headache, diarrhea and joint pain (CARNEIRO,2016;) depression, asthma and hepatotoxicity. For the diagnosis and consequent treatment of these pathologies it is necessary to understand the history of symptomatology, in addition to laboratory tests and in most cases, treatment is effective, bringing complete improvement of the patient (SANTOS et al., 2019).

To assist in this matter, FIOCRUZ's National ToxicPharmacological Information System (SINITOX) has as its main attribution to coordinate the collection, compilation, analysis and dissemination of cases of intoxication and poisoning reported in the country and the years 2013 to 2016 more than 5,500 cases of plant poisoning throughout Brazil, among the age groups children from one to four years of age predominate in all years (SINITOX, 2020)

The importance of the study lies in the growing number of people who make use of these plants, the impossibility of measuring dosages and the use of several herbs simultaneously, increasing their toxicological effects. This article aims to describe the toxicity, effects and undesirable reactions of herbal medicines through the literature review.

\section{Methodology}

The study is defined as a systematic review of the literature based on bibliographic research through articles and scientific publications of reference in the area between the years 2012 and 2021. Being based on Portals such as the Virtual Health Library (VHL) and PubMed, in the databases Science, SciELO, Lilacs, Journals and the federative agency Ministry of Health (MS) and the Oswaldo Cruz Foundation (FIOCRUZ) that is linked with it. It is considered as an inclusion criterion that these publications addressed the theme of rational use of herbal medicines, with emphasis on studies on consumption related to toxicity indices. For this purpose, the key terms 'rational use of herbal medicines' and 'toxicity indices' in these portals were carried out, constituting the selection of 25 articles, which based on this theoretical review.

\section{Results and Discussion}

With the advance of research on the benefits of herbal medicines, it led to increased investments for this area, thus having a preference for use by the population because it is called "natural", easy accessibility, pharmacological conditions among others. In the view of Freitas and Mendonça (2019) despite all these advantages there is still fear among physicians at the time of prescription due to side effects, drug interactions and mainly lack of information on the rational use of herbal medicines.

With this, human intoxication caused by medicinal plants has less notification by the fact that the symptoms observed visibly not be related to the use or exposure of some herbal medicine. According to the National System of Pharmacological Information (SINITOX), in Brazil in 2012 it had $1.2 \%$ equivalent to 1026 registered cases of human intoxication caused by plants. In which, those responsible for notifying the amount of intoxication are the Centers for Information and Pharmacological Assistance (CATs) (MONSENY et al. 2015).

Among the factors associated with herbal toxicity is selfmedication due to the easy availability of purchase because it does not require a prescription, as well as may present toxins, because some herbal medicines are not tested for quality before being imposed for sale. And, another factor is inadequate intake because high dosages used in the long term becomes toxic to the individual. (NAYEEM; FATIMA, 2016).

However, as a way to reduce the risks to the population, the Ministry of Health (MS) reported 71 species of medicinal plants in the list of National List of Physical Plants being governed by the SUS (RENISUS) (Chart 1). This listing had as inclusion criterion plant species that contains scientific proof of its effectiveness, in addition to the use in primary care despite being included in the National Policy of Integrative and Complementary Practice in the SUS (PNPIC) is of paramount importance to health education for rational and safe use.

\begin{tabular}{|c|c|c|c|}
\hline Popular name & Scientific name & Indication & Dosage \\
\hline Aloe & Aloe Vera & $\begin{array}{l}\text { Recommended for } \\
\text { treating } 1^{\circ} \text { - and } 2^{\circ}- \\
\text { degree burns }\end{array}$ & $\begin{array}{l}\text { Dry and glycolic extract. } \\
\text { Topical use: gels, creams } \\
\text { and lotions }\end{array}$ \\
\hline Mint & Piperite Mentha & $\begin{array}{l}\text { Used for treating } \\
\text { irritable } \\
\text { syndrome }\end{array}$ & $\begin{array}{l}\text { Infusion: } 1.5-3 \mathrm{~g} \text { in } 150 \mathrm{ml} \\
\text { of water } 3 \text { times a day } \\
\text { Syrup: }(5 \% \text { Fluid Extract) } \\
20 \text { to } 100 \mathrm{~g} \text { per day. }\end{array}$ \\
\hline Willow & Salix Alba & $\begin{array}{l}\text { Anti-inflammatory } \\
\text { action and widely } \\
\text { used for } \\
\text { inflammation in the } \\
\text { lumbar }\end{array}$ & $\begin{array}{l}\text { Powder: } 1 \text { to } 4 \mathrm{~g} 3 \text { times a } \\
\text { day } \\
\text { Dry extract (3\%): } 200 \text { to } \\
300 \mathrm{mg} \text { daily. }\end{array}$ \\
\hline Guaco & $\begin{array}{l}\text { Mikania } \\
\text { Glomerata }\end{array}$ & $\begin{array}{l}\text { It has expectorant } \\
\text { and bronchodilator } \\
\text { action }\end{array}$ & $\begin{array}{l}\text { Infusion: } 3 \text { to } 5 \mathrm{~g} \text { dry leaves } \\
\text { in } 150 \mathrm{~mL} \text { of hot water, } 3 \\
\text { times a day }\end{array}$ \\
\hline Aroeira & $\begin{array}{l}\text { Schinus } \\
\text { erebenthifolius }\end{array}$ & $\begin{array}{l}\text { Contains healing, } \\
\text { anti-inflammatory } \\
\text { and antiseptic action } \\
\text { for gynecological } \\
\text { use. }\end{array}$ & $\begin{array}{l}\text { Decoction: } 2 \mathrm{~g} \text { dry bark up } \\
\text { to } 3 \text { times a day, with } \\
\text { intervals shorter than } 12 \\
\text { hours. } \\
\text { Tincture: } 2.0 \text { to } 10.0 \mathrm{ml} \text { per } \\
\text { day, divided into } 2 \text { or } 3 \\
\text { doses. }\end{array}$ \\
\hline
\end{tabular}


Among the various benefits of medicinal plants mentioned in Chart 1, it is relevant to expose the toxicity indices, in which Aloe Vera (Babosa) presented hypersensitivity to the substance, especially to individuals with a history allergic to plants of the Lilianceae family who should consequently avoid the use of these preparations (LEAL; TELLIS, 2015).

Mentha piperite (Mint) presents insomnia and irritability in sensitive patients. And in its form essential oils alone possesses the pulegona molecule responsible for causing abortive and convulsive effects. The Salix alba $L$. (Willow) is contraindicated for pregnant and lactating women, because it has toxic substances to the fetus or newborn (MINISTRY OF HEALTH, 2015).

In relation to Schinus terebinthifolius Raddi (Aroeira) in the whole plant there is alchiphenols that is responsible for causing dermatitis and skin in sensitive people (GILBERT AND FAVORETO, 2011). Mikania glomerata (Guaco) has sub chronic toxicity not formed in the literature studied (MINISTRY OF HEALTH, 2018).

The study presented the toxic indices of the herbal medicines offered by SUS; they can cause adverse reactions with interleaving between allopathic drugs. (FELTEN et al, 2015). Among the five most used herbal medicines in the SUS, all presented risks and drug interactions and could potentiate the pharmacokinetics of the active ingredients, causing damage to the health of users.

In relation to the use of herbal medicines deserves attention, the adverse effects caused by medicinal plants, are diarrhea, hepatotoxicity, gastrointestinal alterations, inhibition of platelet aggregation, visual difficulty and neuronal excitability, and that most often users and health professionals do not relate these symptoms to the practice of alternative methods (LEAL; TELLIS, 2015).

The use of medicinal plants passes on traditions and knowledge about a people, but a large part of the younger population does not know how a particular plant species will treat such a disease. Without the minimum of experience with the management in different forms of dosages can cause various damage to health (BUDNIAK and TEIXEIRA ,2018).

According to Felten's (2015) view, the lack of standardization and supervision compromises the sales of herbal medicines, this fact applies to the ease of purchase, insufficient information. (FELTEN et al, 2015). The population created the stereotype because it is natural does not cause damage to health, marketing can be found in supermarkets, pharmacies, natural emporiums and the like. It does not require a prescribing in the health area this principle helps to propagate information without scientific basis.

However, the absence of alternatives for the prevention of excessive use of herbal medicines is important to disseminate by organs linked to the SUS, so that users become aware of the plant or herbal species it is making use of.

The research in question presents toxicities and adverse reactions with indiscriminate use of herbal medicines. Thus, it is necessary that its use be controlled, thus reducing the risks of herbal intoxication.

\section{Conclusions}

After data collection for the construction of this literature review, the importance of Drug Assistance is undeniable, because in Brazil there has been a gradual guarantee of access to medicines and their rational use, especially herbal medicines. In this large department, there is medical care, which aims to prevent the effectiveness of treatment and minimize possible errors to ensure the health of the individual. In addition, pharmaceutical care is not limited to the production and distribution of medicines, but includes a series of drug-focused procedures needed to promote, prevent and restore individual and collective health. With this concept, it covers the activities of research, production, distribution, storage, prescription and dispensing, being basically understood as guiding conducts regarding the proper use and monitoring of medications.

The demand relationship between phytotherapy and pharmaceutical care is obvious. In view of the various benefits that phytotherapy brings to the user, it provides a more affordable treatment and with lower risk of side effects. We observed that the dissemination of herbal medicines and research related to health professionals, especially pharmacists, is flawed, because their training allows guidance on dosage, administration and drug interactions. Therefore, in addition to investing in the expansion of research and knowledge of medicinal plants and the use of herbal medicines, it is evident the importance of training / qualification of health professionals to meet the needs of the population.

\section{References}

[1] ABREU, R. D. S. et al. Assistência farmacêutica em unidades básicas de saúde: um foco no serviço farmacêutico. Braz. J. Hea. Rev., Curitiba, v. 3, n. 4, p. 9797-9911 jul./aug. 2020.

[2] ALENCAR, B. R. et al. Conhecimento dos agentes comunitários de saúde de um município baiano sobre plantas medicinais. Revista Eletrônica de Extensão, v. 16, n. 34, p. $66-84,2019$.

[3] ALMEIDA, M. C.; LOPES, M. B. L. Atuação do enfermeiro na atenção básica de saúde. Revista de Saúde Dom Alberto, v. 3, n. 1, p. 169-186, 2019.

[4] BRASIL. Política e Programa Nacional de Plantas medicinais e Fitoterápicos. Brasília: Ministério da Saúde, $1^{\circ}$ Edição, p. 01-192, 2016

[5] BUDNIAK, A.M; TEIXEIRA, Y. R. A avaliação da percepção e uso da babosa para fins terapêuticos, por acadêmicos de uma instituição de ensino superior. Maringá, PR, 2018

[6] CARneIRO, A. L. C.; COMARElla, L. Principais interações entre plantas medicinais e medicamentos. Revista Saúde e Desenvolvimento, v. 9, n. 5, p. 4-19, 2016.

[7] CORTEZ, D. X. et al. ASSISTÊNCIA 
4 Souza, A.B.Q.; Assunção, S.C.C.; Paiva, M.K.S.; Lacerda, B.G.; Silva, S.G.; Mendonça, R.R.A.; Mendes, I.N.A.; Santos, L.D.P.; Gomes, I.G.S.; Nascimento, E.C.; Gabu, M.C.B.; Oliveira, L.B.S. Phytotherapic medication toxity index: a literature review...

FARMACÊUTICA NO SUS. Revista Interfaces: Saúde, Humanas e Tecnologia, Vol. 2, $\mathrm{N}^{\mathrm{o}} 5$, Ano 2, 2014.

[8] FELTEN, R.D et al. Interações Medicamentosas Associadas a Fitoterápicos Fornecidos pelo Sistema Único de Saúde. Revista Inova Saúde, Criciúma, vol.4, n. 1, Ju,2015. ISSN:2317-2460

[9] FREITAS, R; MENDONÇA, S. B. Hepatopatias: fitoterápicos e interferentes laboratoriais. FACULDADE UNIÃO DE GOYAZES. GOIAS 2019

[10] FUNDAÇÃO OSWALDO CRUZ - FIOCRUZ. SINITOX/ Sistema Nacional de informações TóxicoFarmacológicas 2012. Disponivel em: https://sinitox.icict.FIOCRUZ.br/dados-nacionais Acesso: 28 de setembro de 2021

[11] HERBARIUM LABORATÓRIO BOTÂNICO LTDA. 2009 ALCACHOFRA Cynara scolymus. Disponível em: https://io2.convertiez.com.br/m/drogal/uploads/bulas/78 96083400027/bula-alcachofra-paciente.pdf. Acesso em: 05 de outubro de 2021.

[12] LEAL, L. R., TELLIS, C. J. M., Farmacovigilância de plantas medicinais e fitoterápicos no Brasil: uma breve revisão. Revista Fitos. Rio de Janeiro, Vol., 9(4), 253-303, Out-Dez 2015.

[13] LEE, W. Y. et al. The Methodological Trends of Traditional Herbal Medicine Employing Network Pharmacology. Biomolecules, v. 9, n. 8, p. 362, 2019.

[14] MACEDO, J. A. B. Plantas medicinais e fitoterápicas na atenção primária à saúde: contribuição para profissionais prescritores, 2016.

[15] MINISTÉRIO DA SAÚDE. MONOGRAFIA DA ESPÉCIE Mentha x piperita L. (HORTELÃ PIMENTA) 2015 Disponível em: https://portalarquivos2.saude.gov.br/images/pdf/2017/se tembro/11/Monografia-Mentha-piperita.pdf. Acesso em: 05 de outubro de 2021 . 